\title{
Introduction to Henryk Grossman's critique of Franz Borkenau and Max Weber
}

\section{Rick Kuhn'}

Henryk Grossman ${ }^{2}$ is best known as an economist who developed Marx's theory of the tendency for the rate of profit to fall as an explanation of economic crises (Grossman, 1929a). Apart from his very broad interests, three interrelated sets of experience also equipped him to develop a devastating critique of the argument that the Protestant Ethic underpinned the development of capitalism (Weber, 1968: 68, 170, 174, 181). In 1934, when he wrote about Max Weber's thesis, Grossman could look back on years of political engagement as a Marxist activist; extensive work on economic history and the history of economic thought; and substantial investigations in Marxist economics.

While still a teenager, in the late 1890s, Grossman became involved in the social democratic movement in Kraków, the cultural capital of Galicia, the Polish province of the Austro-Hungarian Empire. While studying at the city's Jagiellonian University he was a leading member of Ruch, an organization of radical students, and began to organize Jewish workers around socialist politics. In 1905 he was the founding secretary and leading theoretician of the newly established Jewish Social Democratic Party of Galicia (JSDP).

Grossman was not an adherent of the mechanical Marxism typical of the Second International and its most prominent theoretician, Karl Kautsky. The pamphlet Bundism in Galicia, which Grossman wrote in 1907 to explain and justify the emergence of the JSDP, anticipated György Lukács's more systematic argument, in the early 1920s, that the working class was both an object and the potential subject of history. In doing so, it presented a nuanced materialist history of ideas and a sophisticated, dialectical analysis of the relationships amongst political organization and consciousness, national oppression and the day-to-day struggles of the Jewish working class.

After a period of relative political inactivity from 1908, Grossman joined the Polish Communist Party in 1920. While he ceased to be a Party member on going into exile from Poland in 1925 and subsequently twice reassessed his attitude to the Soviet Union and international Communist movement, he remained committed to the fundamental Marxist idea of working-class selfemancipation and passionate about politics.

Grossman's Marxism informed his detailed studies in economic history and the history of economic thought. Austria's Trade Policy with Regard to Galicia During the Reform Period of 1772-1790 examined a specific issue in 'the transition from the traditional to the modern mode of production' (Grossmann, 1914). Simonde de Sismondi and His Economic Theories assessed the relationship between the methods and specific arguments of Sismondi and those of Marx (Grossman, 1924). In these and other works, Grossman developed a familiarity with the circumstances under which capitalism emerged in different parts of Europe and a capacity for detailed empirical and textual research.

A central theme of Grossman's best known works on Marxist economic theory, most published when he was with the Institute for Social Research in Frankfurt am Main between 1925 and 1933, was the nature of Marx's scientific method in Capital. From 1919, at the latest, he had argued that

\footnotetext{
* This paper has been accepted for publication in Journal of Classical Sociology and the final (edited, revised and typeset) version of this paper will be published in Journal of Classical Sociology 6(2) July 2006 by Sage Publications Ltd, All rights reserved. (C) Sage Publications Ltd, 2006. www.sagepublications.com.
} 
this involved preliminary abstractions that set aside less important matters in order to reveal fundamental relationships and processes. These matters were then successively reintroduced to make the theory more concrete as an account of empirical reality (Grossman, 1929a, 1929b, 2000 [1922]).

His background in the study of ideology, economic history and scientific method led Grossman, in Parisian exile, to act on a request in March 1934 for a review of The Transition from the Feudal to the Bourgeois World-View by Franz Borkenau (1934). The Institute for Social Research had financed Borkenau's research, the results of which appeared in its journal and monograph series. But the project had become an embarrassment to the Director of the Institute, Max Horkheimer, who approached Grossman. There was a great deal to be criticized in this book on the emergence of modern science, and Grossman became immersed in the project. 'The problem of the origins of mechanistic thought has so gripped me and taken up all of my efforts,' he told Paul Mattick, 'that I have spent almost all of my time for months in the Bibliothèque Nationale in the literature of the 16 th and 17 th centuries.' 3

He wrote a series of essays that demolished different aspects of Borkenau's argument about the emergence of the modern scientific world-view. In an essay on 'The Capitalism of the Renaissance Period', Grossman demonstrated that modern mechanics was elaborated under the influence of capitalist development around 1500, as Engels had remarked in 1877 (Engels, 1976 [1877]: 25). In 'Manufacture of the $16^{\text {th }}-18$ th Centuries', he showed that a systematic division of labour did not become characteristic of manufacture until the second half of the 18th century. In other words, modern mechanics existed before the middle of the 17th century, when Borkenau asserted it arose; and a systematic division of labour, which according to Borkenau explained the formulation of mechanics, only emerged well after that period. A third essay demonstrated that no large-scale enterprises based on manufacture existed before 1661. 'The Beginnings of Capitalism and the New Mass Morality' (Grossman, 2006), provoked by Borkenau's uncritical acceptance of Weber's argument about the relationship between Protestantism and capitalism, is published below for the first time.

After some vacillation, Horkheimer put his foot down and asked Grossman to write the article 'which we originally asked for, namely a correction of the most important methodological and factual errors that B. has made and that today, in a certain way, can become a burden for us'. This was necessary 'to distance us from his work, which in many respects contradicts our own theoretical position, and at the same time to open the discussion of the book'.

Grossman tried but failed to fit and trim his overabundant material into a compact article. Eventually, he gave up and sent a manuscript three to four times the length requested. Horkheimer replied with expansive praise, stating that the article was 'entirely excellent'. ${ }^{6}$ In view of the significance and quality of the work, no entire sections were excised (Grossmann, 1987). The review provided a thorough refutation of the contention that capitalism grew out of craft production (Grossman, 1987 [1935]: 141-51). But it devoted no space to rebutting arguments about the importance of Protestantism that Borkenau took from Weber.

In his first publication - on the Jewish question in the social democratic movement - and his study of Austrian trade policies for Galicia, Grossman had attacked the legends of Jewish cultural inferiority and assimilation, and of the Habsburgs' responsibility for Galicia's backwardness (Grossman, 1905: 42; 1914: 3). 'The Beginnings of Capitalism and the New Mass Morality' demolished the 'legend' of 'the special role of the Protestant Ethic in the origins and development of capitalism'.

The essay made four principal points. Three were explained in the first part of the essay. First, Calvinism emerged as a doctrine of the craft stratum not that of the masses or of the bourgeoisie. It did not serve as a morality that led the masses to accept wage labour; it did not express the interests of the bourgeoisie; and capitalism did not emerge from the stratum of craftspeople. Second, 
capitalism arose two centuries earlier than Calvinism, 'in Italy without any help from religious irrationalism'. This early budding of capitalism was the subject of another of Grossman's critical essays on Borkenau. Third, a crucial aspect of 'education in labour discipline' that Borkenau and Weber neglected was coercion, rather than religion. ${ }^{7}$ The second part of the essay illustrated this point with detailed examples from 17th-century France, supplementing Marx's material on England in Capital (Marx, 1976 [1867]: 896-9). Grossman concluded with his fourth point: that religion in general serves as 'an instrument of mass domestication'. Strands of Catholic thought - the Molinist current in Jesuitism, and Jansenism - were better suited to be mass capitalist moralities than Protestantism.

Before Grossman, other authors, including Richard Tawney (1936: 319-321) with whom he had friendly contact during the mid $1930 \mathrm{~s},{ }^{8}$ had certainly made criticisms of the argument that Protestantism gave a vital impetus to the development of capitalism. But Grossman was one of the first to attack Weber's thesis from a Marxist standpoint. Marx sustained the core of his early assessment of the relationship between Christianity and modern 'civil society' in 'On the Jewish question' (1975) in his later work. A discussion of religion as a reflex of the real world, in Capital for example, argued that Christianity, especially in its bourgeois variants like Protestantism, was appropriate for societies based on commodity production (1976: 172-173).

In 1927, Karl Kautsky took issue with Weber's definition of capitalism and assertion that the impact of Protestantism on economic life disproved historical materialism, while accepting his contention that craftspeople played the decisive role in the emergence of capitalism (1988: 356, 359-360, 369370). Where they commented on The Protestant ethic and the spirit of capitalism, Grossman's other Marxist contemporaries did so favourably. Antonio Gramsci (1971: 338) referred uncritically to the book. György Lukács (1971: 218) and Nikolai Bukharin (1976: 154, 291; 1935: 45) identified Weber's thesis with Marx's position. Grossman's refutation of Weber, based on the method of historical materialism, his own research and Marx's views about religion and analysis of the origins of capitalism, is much more persuasive.

\section{Endnotes}

1 I am grateful to Jack Barbalet for supporting the project of making Grossman's essay available in English and for pointers to the relevant Marxist literature.

2 Grossman always signed his name as 'Henryk Grossman', and this is how he designated himself in all the work whose publication he supervised in Polish and English. In German, his name was generally rendered as Henryk Grossmann. For more about Grossman see Kuhn (2000, 2005, 2006).

3 Letter from Henryk Grossman $n$ to Max Horkheimer, 24 August 1934 (Horkheimer, 1995: 223); letter from Henryk Grossman to Paul Mattick, 2 October 1934 (Grossmann, 1969: 107).

4 Henryk Grossman, 'Der Kapitalismus der Renaissance und die Anfänge der modernen Mechanik', item 7, 'Henryk Grossman', III-155, Archiwum Polskiej Akademii Nauk (APAN); Henryk Grossman 'Die Manufaktur und die wissenschaftliche Mechanik', item 6, APAN; letters from Grossman to Horkheimer, 24 August 1934 (Horkheimer, 1995: 223-24); Grossman to Horkheimer, 16 October 1934 (Horkheimer, 1995: 243-5).

5 Letter from Horkheimer to Grossman, 25 September 1934, Max-Horkheimer-Archiv, Universitäts- und Stadtarchiv, Frankfurt am Main, IV 9 (MHA): 404, referred to in Horkheimer (1995: 225); letter from Horkheimer to Grossman, 8 October 1934 (Horkheimer, 1995: 236-237).

6 Letters from Horkheimer to Grossman, 26 January 1935 (Horkheimer, 1995: 301); 26 October 1934 (Horkheimer, 1995: 254); 4 January 1935 (Horkheimer, 1995: 293-6); 5 January 1935 (Horkheimer, 1995: 297-9).

7 Weber, a wilier writer than Borkenau, noted the existence of 'capitalism' in 14th- and 15th-century Florence and maintained that the Puritans took 'part in the severe English Poor Relief Legislation', referring to developments in the 17th century (1968 [1904-5]: 74, 75, 178, 268). However, these precautions against objections such as those made by Grossman were flimsy. Weber used a very broad definition of 'capitalism' 'that existed in China, India, 
Babylon, in the classic world, and in the Middle Ages'. He did not regard developments in Renaissance Italy as 'modern capitalism' (Weber 1968 [1904-5]: 52), which more closely resembles Marx's capitalist mode of production. Puritan ethics, furthermore, cannot explain English laws against vagabondage and begging introduced in the late 15th and 16th centuries (cf. Marx, 1976 [1867]: 896).

8 Letter from Henryk Grossman to Max Beer, 25 May 1935, Nachlaß Max Beer Box 1, Archiv der sozialen Demokratie der Friedrich-Ebert-Stiftung; letter from Grossman to Horkheimer, 28 January 1936, MHA: 357.

\section{References}

Borkenau, Franz (1934) Der Übergang vom feudalen zum bürgerlichen Weltbild: Studien zur Geschichte der Philosophie der Manufakturperiode. Paris: Alcan

Bukharin, Nikolai Ivanovich (1935) 'Marx's Teaching and its Historical Importance' in N. I. Bukharin, A. M. Deborin, Y. M. Uranovsky, S. L Vavilo, V. L. Komarov and A. I. Tiumeniev. Marxism and Modern Thought. George Routledge \& Sons, London: Routledge: 11-33, (1933)

Bukharin, Nikolai (1976) Historical Materialism: A System of sociology. Anne Arbor: University of Michigan Press. (1920)

Engels, Frederick (1976) Anti-Dühring: Herr Eugen Dühring's Revolution in Science. Peking: Foreign Languages Press. (1877)

Gramsci, Antonio (1971) 'The Study of Philosophy', in The Prison Notebooks. New York: International Publishers: 323-77

Grossman Henryk (1905) Proletariat wobec kwestyi żydowskiej z powodu niedyskutowanej dyskusyi w 'Krytyce'. Kraków: Wladyslawa Teodorczuka

Grossmann, Henryk (1914) Österreichs Handelspolitik mit Bezug auf Galizien in der Reformperiode 1772-1790. Vienna: Konegen

Grossman, Henryk (1924) Simonde de Sismondi et ses théories économiques:. Une nouvelle interprétation de sa pensée. Bibliotheca Universitatis Liberae Polniae, Warsaw/Henryk Grossmann

Grossmann, Henryk (1929a) Das Akkumulations- und Zusammenbruchsgetz des kapitalistischen Systems (zugleich eine Krisentheorie). Leipzig: Hirschfeld

Grossmann, Henryk (1929b) 'Die Änderung des ursprunglichen Aufbauplans des Marxschen “Kapital” und ihre Ursachen' (Grünbergs), Archiv für die Geschichte des Sozialismus und der Arbeiterbewegung 14: 305-38

Grossmann, Henryk (1969) Marx, die klassische Nationalökonomie und das Problem der Dynamik. Frankfurt am Main: Europäische Verlaganstalt.

Grossmann, Henryk (1987) 'The Social Foundations of Mechanistic Philosophy and Manufacture', Science in Context 1: 129-80. (1935: 'Die gesellschaftlichen Grundlagen der mechanistischen Philosophie und die Manufaktur', Zeitschrift für Sozialforschung 4 (2): 161-231)

Grossman, Henryk (2000) 'The Theory of Economic Crises', Research in Political Economy 18: 171-80. (1922: 'Teorja kryzysów gospodarczych' (The Theory of Economic Crises)', Bulletin International de l'Académie Polonaise des Sciences et des Lettres. Classe de Philologie. Classe d'Histoire et de Philosophie. Les Années 1919. 1920 (presented 16 June 1919), Kraków: 285-90)

Grossman, Henryk (2006) 'The Beginnings of Capitalism and the New Mass Morality' Journal of Classical Sociology 6 (2): July

Horkheimer, Max (1995) Gesammelte Schiften 15: Briefwechsel 1913-1936. Frankfurt am Main: Fischer

Kautsky, Karl (1988) The Materialist Conception of History. New Haven: Yale University Press. (1927)

Kuhn, Rick (2000) 'Henryk Grossman, a Marxist Activist and Theorist: On the 50th Anniversary of his Death', Research in Political Economy 18: 111-70 
Kuhn, Rick (2005) 'Henryk Grossman and the Recovery of Marxism', Historical Materialism 13 (3): $57-100$

Kuhn, Rick (2006) Henryk Grossman. Champaign: University of Illinois Press.

Lukács, Georg (1971) History and Class Consciousness. London: Merlin

Marx, Karl (1975) 'On the Jewish Question', pp. 212-41 in Early Writings. Harmondsworth: Penguin. (1843)

Marx, Karl (1976) Capital: A Critique of Political Economy, Vol. 1. Harmondsworth: Penguin. (1867)

Tawney, Richard (1936) Religion and the Rise of Capitalism: A Historical Study. London: Murray. (1926)

Weber, Max (1968) The Protestant Ethic and the Spirit of Capitalism. London: Unwin. (1904-5) 